\title{
The Opportunity Costs of Rent Seeking
}

\author{
Tyler Cowen \\ Department of Economics \\ George Mason University
}

Fairfax, VA 22030

Alexander Tabarrok

Department of Economics

George Mason University

Fairfax, VA 22030 


\section{The Opportunity Costs of Rent Seeking}

Abstract: The costs of rent seeking exceed traditional measures when opportunity cost is considered. When the quantity of resources consumed by rent seeking is large, rent seeking draws consumer surplus out of alternative resource employments. The costs of rent seeking differ in partial and general equilibrium frameworks; Tullock (1989) recognizes this but incorrectly argues that rent seeking costs are twice as large in general than in partial equilibrium. Other authors suggest that rent seeking costs are lower once the opportunity costs of resources used in rent seeking are considered. We clear up the confusion in the current literature.

JEL Classification: D72

Keywords: Rent seeking 


\section{Introduction}

The literature on rent seeking argues that the Harberger deadweight loss triangle underestimates the welfare costs of monopoly, tariffs, and theft (TULLOCK, 1967). Rents from these activities are not mere transfers from consumers to producers. In equilibrium, these rents are dissipated in the process of competing to attain them. With perfect competition, no strategic behavior, and risk neutrality the rents are completely dissipated. We show this loss in Figure One as $\mathrm{H}+\mathrm{C}{ }^{1}$

When the quantity of resources invested in rent seeking is large, as suggested by many analysts, traditional measures underestimate rent seeking costs. ${ }^{2}$ Rent seeking costs include the general equilibrium loss of consumer surplus when resources are drawn into rent seeking activity. The total size of these losses exceeds the traditional rent seeking loss rectangle. The complete cost of all rent seeking activities is the summation of resources exhausted in seeking rents plus the consumer surplus that could be created if rent seeking resources were switched to productive endeavors.

We now illustrate our basic point with a simple example and compare our analysis to the claims made by Tullock (1989). In section three we consider further implications of the distinction between partial and general equilibrium effects.

\footnotetext{
${ }^{1}$ For purposes of expositional simplicity, we focus on the case of complete dissipation. The subsequent literature on rent seeking has sought to explain the conditions under which rents are fully dissipated, and how various assumptions effect the extent of dissipation. Modifying the assumptions of perfect competition, risk neutrality and no strategic behavior can increase or decrease the extent of rent seeking costs. See for example ROGERSON (1982), HILLMAN KATZ (1984) and TULLOCK (1980). Tollison (1982) and Mueller (1989, Ch. 13) survey the literature on rent seeking more generally.

${ }^{2}$ For estimates or rent seeking loss see POSNER (1975) and LABAND - SOPHOCLEUS (1992).
} 


\section{The costs of theft}

We start with the example of thieves, whom we treat as rent-seekers. Thieves consume resources in the form of guns, crowbars, etc. in their efforts to break into houses and steal goods. With perfect competition in all markets the quantity of resources invested in burglary equals the expected booty and thieves earn no excess profits. Thieves will earn no more than the wage rate available in other employments.

The value of the resources consumed in theft represents the social loss from rent seeking. The cost of theft to society is the loss to the victim (C), minus the gain to the thief $(C)$, plus the opportunity cost to the thief of stealing (L).

1) Cost of Theft $=C-C+L=L$

In perfect competition resources earn the same return in all employments and the thief earns zero economic profit so $\mathrm{L}=\mathrm{C}$. We thus can measure the costs of rent seeking indirectly by measuring the value of the rent that is sought $(\mathrm{C})$. For example, the cost of theft is the value of the goods stolen (which is equal to the value of the thief's time and investment in crowbars) and the cost of a tariff is equal to the increased revenue the tariff provides (plus the Harberger triangle). If the magnitude of rent seeking behavior is small relative to the economy as a whole, there is no further opportunity cost of rent seeking. Imagine that one thief switches from theft to plumbing. The total gain to society from the switch is $\mathrm{C}$ plus any Harberger triangle. Prices of plumbing services are not altered perceptibly, and consumers gain no additional consumer surplus from the switch. The payment that consumers make to the new plumber exactly equals the value of his services. The plumber receives the value of his marginal product and consumes this marginal product, just like the thief. ${ }^{3}$

\footnotetext{
${ }^{3}$ To be precise consumers earn an epsilon of additional consumer surplus and the thief loses an epsilon. We ignore these gains and losses for expositional convenience.
} 
In contrast, consumer surplus increases if many workers switch from theft to plumbing. Assume that opportunities for theft disappear and inputs previously used in theft shift into the plumbing sector to significant degree. Output will rise and prices will fall in the plumbing industry, and total consumer surplus will increase. ${ }^{4}$

\section{Comparison with Others}

Several other writers consider general equilibrium treatments of rent seeking costs but they do not present our point. Tullock correctly recognizes that the true cost of rent seeking <<is greater than previous scholars (including Tullock) have realized $(1989,14)$. > The true cost of theft, according to Tullock, is the wasted resources the thief uses in burglary plus the total value of the plumbing services the thief would create were he not a thief (call this A). Under perfect competition the thief's product in alternative employment $(A)$ is exactly equal to the thief's opportunity cost of theft $(\mathrm{L})$ which equals the value of the resources he wastes in burglary $(\mathrm{C})$. Therefore Tullock (1989) argues that the true cost of theft is $2 \mathrm{C}$ - twice that in the traditional literature! ${ }^{5}$

\footnotetext{
${ }^{4}$ A similar point was made in the "Brain Drain" controversy of the mid-1960's. Grubel and Scott (1966) argued that the brain drain was a non-issue because a worker in a competitive economy is paid the value of his marginal product. If the worker emigrates society loses the marginal product but it no longer has to pay the worker. National product declines but the effective demand for output falls by an equal amount. Real income for those remaining is therefore constant. This analysis breaks down when one considers <<non-marginal reductions in particular types of labor >> (KINDLEBERGER - HERRICK 1977, 105). The withdrawal of large amounts of labor means that <<the marginal product of all other factors taken together falls $(\mathrm{K} \& \mathrm{H}, 106),>>$ and society experiences welfare losses.

${ }^{5}$ Tullock's actual example concerns Luddites who destroy valuable machinery in order to earn rents on other resources. In this case the loss to society is equal to the value of the rent plus the value of the broken machinery. We do not dispute that the broken machinery is a loss to society. Tullock, however, wishes to add to these losses the $<<$ loss of what would have been produced if the same resources had been used productively (16).>> That is, the positive product the Luddites would have produced if they had not broken machinery. It is this last point we dispute for the reasons in
} 
Tullock's argument, however, is incorrect. The difference between our measure of rent seeking cost and Tullock's can be seen by considering the shift of a single thief from thievery into plumbing. Since the thief cannot effect prices in the plumbing industry no additional consumer surplus is created and the cost of rent seeking is $\mathrm{C}$ only. The product of the thief in the productive sector (A) does not accrue to society, but instead accrues to the former thief. ${ }^{6}$ Society's welfare gain is only the resources no longer used in burglary, it does not include the thief's product as a plumber because society pays this product to the former thief.

In contrast, if all thieves shift to the plumbing sector then the consumer surplus created by that product counts as a social gain (as opposed to counting the value of their product). The consumer surplus created by the thief's product is determined by the elasticity of the demand curve in the productive sector. If the elasticity in the productive sector equals one, then $\mathrm{C}$ in resources will create $\mathrm{C}$ plus the Harberger triangle in consumer surplus. If the elasticity is smaller than one, consumer surplus gains are smaller and if elasticity is greater than one the gains are larger.

Tullock's measure does not distinguish between marginal and inframarginal changes. The return to the marginal plumber goes entirely to the plumber and not to society. Only when many thieves shift to plumbing does society gain over and above the rent seeking cost of theft. In this case the additional gain is the consumer surplus created by the new plumbers, and not their total product as Tullock argues.

the text. Since we are in agreement concerning the costs of the broken machinery we eliminated this issue from our discussion.

${ }^{6}$ We include the thief's utility in our welfare calculations. Since the theft and plumbing industries are perfectly competitive, the thief earns the same return in either industry. What the thief gains from plumbing he loses from theft. Since the thief's gains and losses are a wash we focus on the gains and losses to society. For an argument that the thief's utility should not be included in welfare calculations see LEWIN - TRUMBULL (1990). 
The distinction between partial and general equilibrium welfare effects, when large resource shifts are involved, has not been applied consistently. Brooks and Heijdra (1988), are perhaps closest to our analysis in that they recognize a $<<$ strict partial equilibrium framework cannot be used to examine the effects of rent seeking (33).>> Their general equilibrium model, however, leads them to conclude that Harberger was correct after all - only the triangle of dead weight loss is a true social cost. This odd result is due to their assumption that bureaucrats receive the entire rent as a transfer payment and that no real resources are consumed. Congleton (1988, p.183), clarifies this issue and notes that the Tullock rectangle understates the opportunity cost of rent seeking activities if resources used in rent seeking flow from industries earning supra-normal profits. Congleton's analysis, however, does not differ from the standard approach when markets are perfectly competitive. Our analysis, in contrast, concerns changes in consumer surplus due to inframarginal resource shifts and applies under any market conditions. ${ }^{7}$

\section{Rent seeking and constitutional economics}

We have pinpointed one factor indicating that the social costs of rent seeking are higher than had previously been believed. When attempting to estimate the total costs of rent seeking in an economy (e.g., LABAND - SOPHOCLEUS 1992, POSNER 1975) we should include foregone consumer surplus in other industries.

Our analysis also has relevance, however, when we measure the costs of rent seeking in only a single industry or sector. Even if foregone consumer surplus is very small or zero in a particular case, we should not ignore the potential for a single decision, when combined with

\footnotetext{
${ }^{7}$ Bhagwati $(1980,1982)$ also argues that market prices may not reflect the true shadow value of resources when estimating the costs of rent-seeking. But Bhagwati focuses upon the case where rent-seeking may be welfare-improving when the resources employed in rent-seeking have a negative shadow value. Bhagwati does not consider the general under-valuation of rent-seeking costs which occurs when large resource shifts are analyzed as if marginal valuation applied to the entire shift.
} 
others, to produce general equilibrium effects. Consider an economy where rent seeking occurs in two hundred separate (small) industries. Eliminating rent seeking in any one industry would not increase consumer surplus appreciably but eliminating rent seeking in all industries would. If we approach rent seeking on a case by case basis, we will eliminate less rent seeking than is rational. Partial equilibrium cost-benefit analysis does not take into account the ability of many partial equilibrium costs to sum to a non-negligible general equilibrium cost.

Following a partial equilibrium approach may even lead us into paradox. Partial equilibrium cost-benefit analysis may lead us to accept the marginal rent seeking industry, and therefore all rent seeking industries. Yet, total rent seeking costs can be so large that we prefer to prohibit as much rent seeking as possible. The first step in any journey is waste (because negligible) yet still the journey may be worth taking. For this reason, we may wish to consider large scale effects even when evaluating isolated instances of rent seeking. We might, for instance, recognize the total cost of rent seeking by adopting a constitutional amendment to limit rent seeking behavior. Without an eye for large or general equilibrium effects, an economic constitution based upon cost-benefit analysis can undercut itself. When we measure the effects of a single decision, we should consider how this decision may interact with other changes. Similarly, when economists give politicians advice about the costs of rent seeking, they should consider how much impact their advice is likely to have. The cost estimates of the economist may depend upon how much of his or her advice is implemented; i.e., how much rent seeking behavior is curtailed 


\section{References}

BhaGWATI, N, J, 1980, <<Lobbying and welfare>>, Journal of Public Economics, 14, 355363.

BHAGWATI, N. J., 1982, <<Directly unproductive, profit seeking (DUP) activities>>, Journal of Political Economy, 90, \#5, 988-1002.

Brooks, M.A., - Heijdra, B.J., 1988, <<ln search of rent seeking >>, in C. Rowley, R.D. TOlLISON, R. - G. TULLOCK (eds), The Political Economy of Rent Seeking, Boston, MA: Kluwer Academic Publishers, 27-49.

BUCHANAN, J.M., 1980, <<Reform in the rent-seeking society >>, in J.M. Buchanan, R.D. TOLLISON, R.D. - G. Tullock (eds). Toward a Theory of the Rent-Seeking Society, College Station, TX: Texas A \& M Press.

CONGLETON, R.D., 1988, <<Evaluating rent seeking losses: Do the welfare gains of lobbyists count?>>, Public Choice, 56, 181-184.

GRuBEL, H. - ScotT, A.,1966, <<The International Flow of Human Capital >>, American Economic Review56, \#2 (March): 268-283.

HILLMAN, A.L., - KATZ, E., 1984, <<Risk-Averse rent seekers and the social cost of monopoly power>>, The Economic Journal, 94 (March), 104-110.

Kindleberger, C. - HerRick, B., 1977, Economic Development: Economics Handbook Series, 3rd ed, New York, NY: McGraw-Hill Book Co.

LABAND, D.N. - J.P. SOPHOCLEUS., 1992, <<An Estimate of Resource Expenditures on Transfer Activity in the United States>>, Quarterly Journal of Economics CVII, \#3 (Aug.), 959-984.

LEWIN, J.L. - TRUMBULL W.N., 1990, <<The Social Value of Crime?>> International Review of Law and Economics, 10, \#3 (Dec.), 271-284.

POSNER, R.A., 1975, <<The social costs of monopoly and regulation >>, Journal of Political Economy, 83, \#4 (Aug.), 807-827. 
ROGERSON, W., 1982, <<The social costs of monopoly and regulation: A game theoretic approach>>, Bell Journal of Economics, 13, 391-401.

TOLLISON, R.D., 1982, <<Rent seeking: A survey>>, Kyklos, 35, 575-602.

TULLOCK, G., 1967, <<The welfare costs of tariffs, monopoly and theft>>, Western Economic Journal, 5 (June), 224-232.

TULLOCK, G., 1988, <<Rents and rent seeking >>, in C. Rowley, R.D. Tollison and G. Tullock (eds). The Political Economy of Rent Seeking, Boston, MA: Kluwer Academic Publishers, 51-62.

TULLOCK, G., 1989, The Economics of Special Privilege and Rent Seeking, Boston, MA: Kluwer Academic Publishers. 


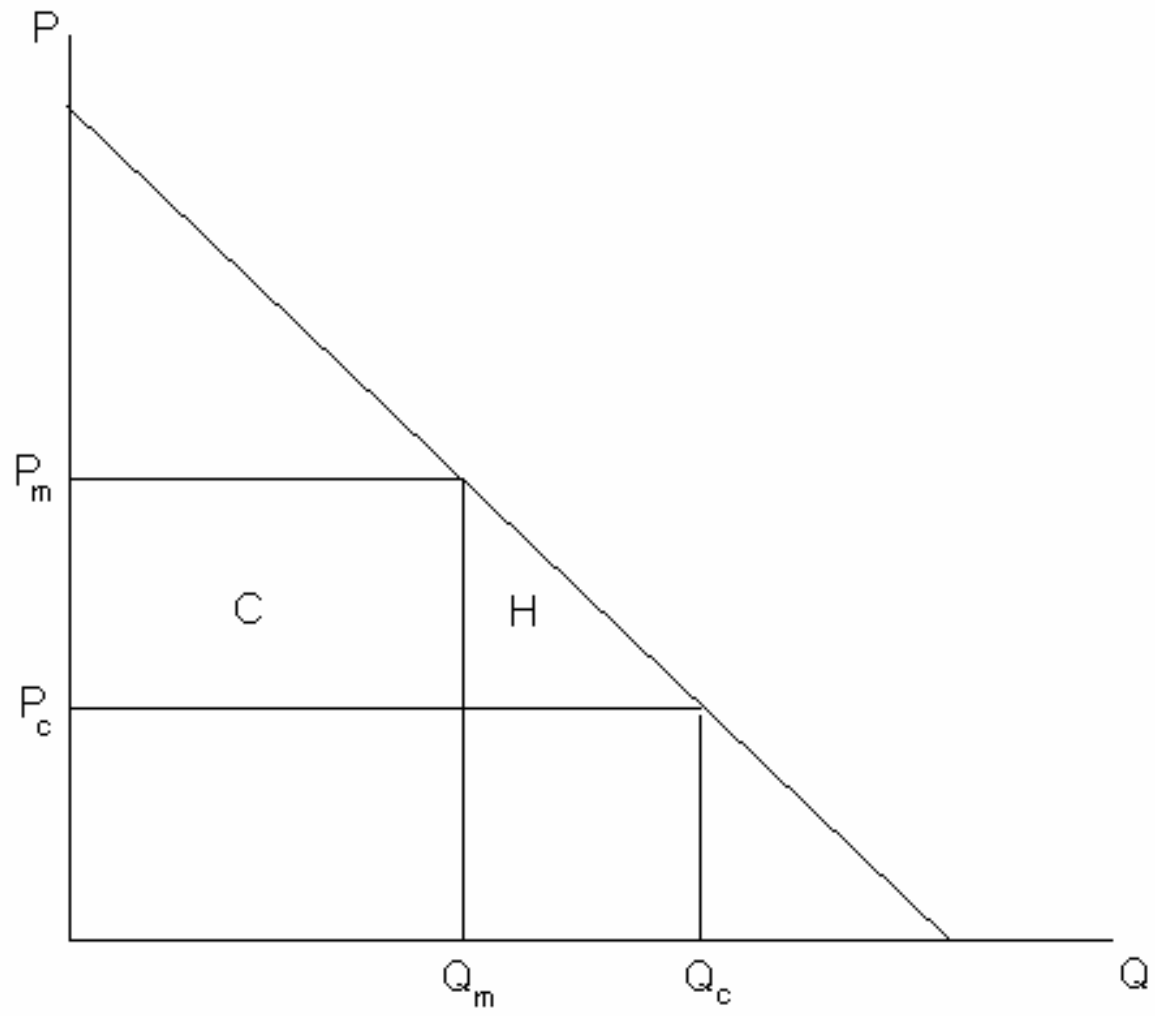

Figure 1: Rent Dissipation 